\title{
ANALISIS PERAN DAN ORIENTASI PEMERINTAH DAERAH DALAM OPTIMALISASI PENGELOLAAN PENDAPATAN ASLI DESA DAN ALOKASI DANA DESA (Studi Kasus pada Pemerintah Desa Kalibukbuk, Kec.Buleleng)
}

\author{
Putu Yunik Widiarini, A. A. Ayu Mirah Permata Sari, \\ Kadek Ayu Mas Mirayani, Luh Keristina \\ Jurusan Akuntansi, Universitas Pendidikan Ganesha, Singaraja, Bali, Indonesia
}

\begin{abstract}
Abstrak
Penelitian ini bertujuan untuk mengetahui peran dan orientasi Pemerintah Desa kalibukbuk dalam mengoptimalisasi pengelolaan pendapatan asli desa dan alokasi dana desa. Metode analisis data yang digunakan dalam melakukan analisis keuangan dilakukan dengan menggunakan metode kualitatif. Dalam penelitian ini, data diperoleh melalui Data Primer dan Data Sekunder. Data penelitian ini didapatkan dengan wawancara yang dilakukan oleh peneliti kepada Putu Lisa Swandewi sebagai Koordinator Keuangan di Kantor Perbekel Kalibukbuk, yang sudah disampaikan beberapa pertanyaan yang menunjang dari penelitian ini. Berdasarkan hasil penelitian di atas dapat disimpulkan bahwa proses pelaksanaan APBDesa mengacu pada realisasi pembangunan fisik dan non fisik yang telah direncanakan sebelumnya. Maka dari itu perencanaan kegiatan pembangunan dan pemeliharaan jalan lingkungan sudah terealisasi pada tahun 2018. Faktor pendukung dari pelaksanaan program Pendapatan Asli Desa dan Alokasi Dana Desa adalah tingginya sumber daya masyarakat dan partisipasi masyarakat yakni dalam Musyawarah Desa.
\end{abstract}

Kata kunci: Pendapatan, Dana Desa, Optimalisasi

\begin{abstract}
This study aims to determine the role and orientation of the Kalibukbuk Village Government in optimizing the management of original village income and the allocation of village funds. The data analysis method used in conducting financial analysis is carried out using qualitative methods. In this study, data were obtained through Primary Data and Secondary Data. The data of this study were obtained by interviews conducted by researchers with Putu Lisa Swandewi as the Financial Coordinator at the Kalibukbuk Perbelel Office, which had raised several questions that support the research. Based on the above research results it can be concluded that the process of implementing the APBDesa refers to the realization of physical and non-physical development that had been planned beforehand. Therefore planning for the construction and maintenance of environmental roads has been realized in 2018. Supporting factors for the implementation of the Village Original Revenue program and Village Fund Allocation are high community resources and community participation, namely in the Village Deliberation.
\end{abstract}

Keywords : income, Village Funds, Optimization

\section{Pendahuluan}

Negara adalah suatu wilayah di permukaan bumi yang diatur oleh pemerintahan yang berada di wiayah tersebut. Syarat terbentuknya suatu negara yakni memiliki rakyat, wilayah dan pemerintahan yang berdaulat. Pemerintahan adalah perangkat untuk mengendalikan dan mengarahkan suatu negara, yang mempunyai bermacam-macam cara untuk mengatasi persoalan-persoalan kenegaraan atas nama rakyat berdasarkan hukum yang berlaku. Pemerintah dalam arti sempit dapat didefinisikan dari segi struktural fungsional sebagai sebuah sistem struktur dan organisasi dari berbagai macam fungsi yang dilaksanakan atas dasar-dasar tertentu untuk mencapai tujuan negara. (Haryanto, dkk, 1997:2-3). Sedangkan pemerintah dalam arti luas menurut C.F.Strong mendefinisikan bahwa pemerintahan sebagai segala aktivitas badan-badan publik yang meliputi kegiatan legislatif, eksekutif, dan yudikatif dalam usaha untuk mencapai tujuan negara.

Di setiap negara tentunya memiliki bentuk pemerintahan, untuk mengarahkan suatu negara dalam mencapai tujuannya. Bentuk Pemerintahan Negara Indonesia adalah 
Republik. Tujuan dari pemerintahan negera Indonesia tercantum di pembukaan UndangUndang Dasar Negara Republik Indonesia Tahun 1945 alinea ke-4 yang berbunyi, "Kemudian daripada itu untuk membentuk suatu Pemerintah Negara Indonesia yang melindungi segenap Bangsa Indonesia dan seluruh tumpah darah Indonesia dan untuk memajukan kesejahterakan umum, mencerdaskan kehidupan bangsa dan ikut melaksanakan ketertiban dunia yang berdasarkan kemerdekaan, perdamaian abadi dan keadilan sosial, maka disusunlah kemerdekaan, kebangsaan Indonesia itu dalam suatu Undang-Undang Dasar Negara Indonesia, yang terbentuk dalam suatu susunan Negara Republik Indonesia yang berkedaulatan rakyat dengan berdasar kepada Ketuhanan Yang Maha Esa, Kemanusiaan yang Adil dan Beradab, Persatuan Indonesia, dan Kerakyatan yang dipimpin oleh hikmat kebijaksanaan dalam permusyawaratan/perwakilan, serta dengan Mewujudkan suatu Keadilan Sosial bagi Seluruh Rakyat Indonesia".

Undang-Undang di Indonesia membagi kekuasaan kepada bebrapa lembaga negara yang sama dan sejajar. Pembagian kekuasaan ini berdasarkan pada Undang-Undang Dasar Pasal 4 ayat 1 tentang Sistem Pemerintahan Indonesia. Presiden merupakan pemegang kekuasaan tertinggi dalam pemerintahan Negara Indonesia yang memiliki wewenang yakni sebagai kepala pemerintah dan sebagai kepala negara. Dalam Pemerintah Daerah Tingkat I yakni Dewan Perwakilan Rakyat Daerah (DPRD) Provinsi, pemegang kekuasaan tertinggi di Provinsi adalah Gubernur. Dewan Perwakilan Daerah Tingkat II adalah Kabupaten atau Kota Madya, pemeganga kekekuasaan tertinggi yaitu Bupati atau Wali Kota. Setelah DPR Tingkat II yaitu Pemerintahan Kecamatan, pemegangang kekuasaan tertinggi adalah Camat. Dan Sistem Pemerintahan paling rendah adalah tingkat Desa atau Kelurahan, dan pemegang kekuasaan tertinggi adalah Kepala Desa atau Lurah.

Sebagaiamana yang dinyatakan dalam Undang-Undang Nomor 6 Tahun 2014 tentang desa, yakni penatausahaan keuangan Pemerintah Desa terpisah dari keuangan Pemerintah Kabupaten. Desa telah menjadi kesatuan masyarakat hukum yang memiliki batas wilayah yang berwenang untuk mengatur dan mengurus kepentingan masyarakat setempat beserta urusan pemerintahaan berdasarkan prakarsa, asal-usul dan adat istiadat masyarakat setempat serta hak tradisional yang diakui dan dihormati dalam sistem pemerintahan Negara Kesatuan Republik Indonesia (NKRI).

Anggaran Pendapatan dan Belanja Desa (APBD) adalah peraturan desa yang berisikan sumber-sumber penerimaan dan pengalokasian pengeleuaran desa dalam kurun waktu satu tahun. APBDesa terdiri dari pendapatan desa, belanja desa dan pembiayaan. Pendapatan desa berasal dari pendapatan asli desa yakni dari hasil usaha, aset, swadaya, partisipasi, dan pendapatan lain asli desa yang sah serta berasal dari transfer Hasil Pajak Daerah Kabupaten/Kota dan Retribusi Daerah. Di samping itu pendapatan desa juga berasal dari bantuan keuangan dari APBD Provinsi, dan pendapatan lain-lain, yakni hibah dan sumbangan dari pihak ketiga yang tidak mengikat. Klasifikasi belanja desa terdiri atas penyelenggaraan pemerintahan desa, pelaksanaan pembangunan desa, pembinaan kemasyarakatan desa, pemberdayaan masyarakat desa, dan belanja tak terduga yang telah dituangkan dalam Rencana Kerja Pemeritah Desa (RKPDesa).

Sedangkan pembiayaan desa terdiri dari penerimaan pembiayaan dan pengeluaran pembiayaan. Adapun penerimaan pembiayaan adalah sisa lebih perhitungan anggaran (SiLPA) tahun sebelumnya, pencarian dana cadangan, dan hasil penjualan kekayaan desa yang dipisahkan. Adapun pengeluaran pembiayaan adalah pembentukan dana cadangan dan penyertaan dana desa. (bd03, 2015). Pembangunan daerah merupakan salah satu rangkaian dasar keberhasilan dari pembangunan nasional yang bertujuan untuk meningkatkan taraf hidup dan kesejahteraan rakyat. Pelaksanaan pembangunan secara efektif dan efisien akan mewujudkan tercapainya kemandirian daerah diarahkan juga untuk pelaksanaan otonomi daerah telah muncul undang-undang yaitu Undang-Undang Nomor 22 Tahun 1999 Tentang Pemerintah Daerah dan UU Nomor25 Tahun 1999 Tentang Pertimbangan Keuangan Antara Pemerintah Pusat dan Daerah. Dari beberapa pendapat warga Desa Kalibukbuk mengenai akses jalan kecil atau gang yang masih kurang layak, tidak berupa beton membuat warga Desa Kalibukbuk merasa terganggu karena apabila musim hujan tiba maka akses jalan kecil menuju rumah warga yang masih berupa tanah 
akan menjadi licin. Ironisnya meski sudah mengalami kerusakan sejak beberapa bulan, namun hingga kini belum diperbaiki. Gang kecil tersebut hanya ditutupi dengan limbah genteng yang bertujuan agar tak ada pengguna akses jalan kecil tersebut tergelincir saat melintas gang tersebut. Menurut Luh Geria, selaku warga Desa Kalibukbuk menyebutkan sebagai destinasi wisata Desa Kalibukbuk harus memberikan kenyamanan dan keselamatan bagi para wisatawan yang ingin mengunjungi Desa Kalibukbuk. Berdasarkan permasalahan di atas penulis mengangkat judul "Analisis Peran dan Orientasi Pemerintah Desa Dalam Optimalisasi Pengelolaan Pendapatan Asli Desa dan Alokasi Dana Desa (Studi Kasus pada Pemerintah Desa Kalibukbuk, Kecamatan Buleleng)".

Negara adalah suatu wilayah di permukaan bumi yang diatur oleh pemerintahan yang berada di wiayah tersebut. Syarat terbentuknya suatu negara yakni memiliki rakyat, wilayah dan pemerintahan yang berdaulat. Pemerintahan adalah perangkat untuk mengendalikan dan mengarahkan suatu negara, yang mempunyai bermacam-macam cara untuk mengatasi persoalan-persoalan kenegaraan atas nama rakyat berdasarkan hukum yang berlaku. Pemerintah dalam arti sempit dapat didefinisikan dari segi struktural fungsional sebagai sebuah sistem struktur dan organisasi dari berbagai macam fungsi yang dilaksanakan atas dasar-dasar tertentu untuk mencapai tujuan negara. (Haryanto, dkk, 1997:2-3). Sedangkan pemerintah dalam arti luas menurut C.F.Strong mendefinisikan bahwa pemerintahan sebagai segala aktivitas badan-badan publik yang meliputi kegiatan legislatif, eksekutif, dan yudikatif dalam usaha untuk mencapai tujuan negara.

Di setiap negara tentunya memiliki bentuk pemerintahan, untuk mengarahkan suatu negara dalam mencapai tujuannya. Bentuk Pemerintahan Negara Indonesia adalah Republik. Tujuan dari pemerintahan negera Indonesia tercantum di pembukaan UndangUndang Dasar Negara Republik Indonesia Tahun 1945 alinea ke-4 yang berbunyi, "Kemudian daripada itu untuk membentuk suatu Pemerintah Negara Indonesia yang melindungi segenap Bangsa Indonesia dan seluruh tumpah darah Indonesia dan untuk memajukan kesejahterakan umum, mencerdaskan kehidupan bangsa dan ikut melaksanakan ketertiban dunia yang berdasarkan kemerdekaan, perdamaian abadi dan keadilan sosial, maka disusunlah kemerdekaan, kebangsaan Indonesia itu dalam suatu Undang-Undang Dasar Negara Indonesia, yang terbentuk dalam suatu susunan Negara Republik Indonesia yang berkedaulatan rakyat dengan berdasar kepada Ketuhanan Yang Maha Esa, Kemanusiaan yang Adil dan Beradab, Persatuan Indonesia, dan Kerakyatan yang dipimpin oleh hikmat kebijaksanaan dalam permusyawaratan/perwakilan, serta dengan Mewujudkan suatu Keadilan Sosial bagi Seluruh Rakyat Indonesia".

Undang-Undang di Indonesia membagi kekuasaan kepada bebrapa lembaga negara yang sama dan sejajar. Pembagian kekuasaan ini berdasarkan pada Undang-Undang Dasar Pasal 4 ayat 1 tentang Sistem Pemerintahan Indonesia. Presiden merupakan pemegang kekuasaan tertinggi dalam pemerintahan Negara Indonesia yang memiliki wewenang yakni sebagai kepala pemerintah dan sebagai kepala negara. Dalam Pemerintah Daerah Tingkat I yakni Dewan Perwakilan Rakyat Daerah (DPRD) Provinsi, pemegang kekuasaan tertinggi di Provinsi adalah Gubernur. Dewan Perwakilan Daerah Tingkat II adalah Kabupaten atau Kota Madya, pemeganga kekekuasaan tertinggi yaitu Bupati atau Wali Kota. Setelah DPR Tingkat II yaitu Pemerintahan Kecamatan, pemegangang kekuasaan tertinggi adalah Camat. Dan Sistem Pemerintahan paling rendah adalah tingkat Desa atau Kelurahan, dan pemegang kekuasaan tertinggi adalah Kepala Desa atau Lurah.

Sebagaiamana yang dinyatakan dalam Undang-Undang Nomor 6 Tahun 2014 tentang desa, yakni penatausahaan keuangan Pemerintah Desa terpisah dari keuangan Pemerintah Kabupaten. Desa telah menjadi kesatuan masyarakat hukum yang memiliki batas wilayah yang berwenang untuk mengatur dan mengurus kepentingan masyarakat setempat beserta urusan pemerintahaan berdasarkan prakarsa, asal-usul dan adat istiadat masyarakat setempat serta hak tradisional yang diakui dan dihormati dalam sistem pemerintahan Negara Kesatuan Republik Indonesia (NKRI).

Anggaran Pendapatan dan Belanja Desa (APBD) adalah peraturan desa yang berisikan sumber-sumber penerimaan dan pengalokasian pengeleuaran desa dalam kurun waktu satu tahun. APBDesa terdiri dari pendapatan desa, belanja desa dan pembiayaan. 
Pendapatan desa berasal dari pendapatan asli desa yakni dari hasil usaha, aset, swadaya, partisipasi, dan pendapatan lain asli desa yang sah serta berasal dari transfer Hasil Pajak Daerah Kabupaten/Kota dan Retribusi Daerah. Di samping itu pendapatan desa juga berasal dari bantuan keuangan dari APBD Provinsi, dan pendapatan lain-lain, yakni hibah dan sumbangan dari pihak ketiga yang tidak mengikat. Klasifikasi belanja desa terdiri atas penyelenggaraan pemerintahan desa, pelaksanaan pembangunan desa, pembinaan kemasyarakatan desa, pemberdayaan masyarakat desa, dan belanja tak terduga yang telah dituangkan dalam Rencana Kerja Pemeritah Desa (RKPDesa).

Sedangkan pembiayaan desa terdiri dari penerimaan pembiayaan dan pengeluaran pembiayaan. Adapun penerimaan pembiayaan adalah sisa lebih perhitungan anggaran (SiLPA) tahun sebelumnya, pencarian dana cadangan, dan hasil penjualan kekayaan desa yang dipisahkan. Adapun pengeluaran pembiayaan adalah pembentukan dana cadangan dan penyertaan dana desa. (bd03, 2015). Pembangunan daerah merupakan salah satu rangkaian dasar keberhasilan dari pembangunan nasional yang bertujuan untuk meningkatkan taraf hidup dan kesejahteraan rakyat. Pelaksanaan pembangunan secara efektif dan efisien akan mewujudkan tercapainya kemandirian daerah diarahkan juga untuk pelaksanaan otonomi daerah telah muncul undang-undang yaitu Undang-Undang Nomor 22 Tahun 1999 Tentang Pemerintah Daerah dan UU Nomor25 Tahun 1999 Tentang Pertimbangan Keuangan Antara Pemerintah Pusat dan Daerah.

Dari beberapa pendapat warga Desa Kalibukbuk mengenai akses jalan kecil atau gang yang masih kurang layak, tidak berupa beton membuat warga Desa Kalibukbuk merasa terganggu karena apabila musim hujan tiba maka akses jalan kecil menuju rumah warga yang masih berupa tanah akan menjadi licin. Ironisnya meski sudah mengalami kerusakan sejak beberapa bulan, namun hingga kini belum diperbaiki. Gang kecil tersebut hanya ditutupi dengan limbah genteng yang bertujuan agar tak ada pengguna akses jalan kecil tersebut tergelincir saat melintas gang tersebut. Menurut Luh Geria, selaku warga Desa Kalibukbuk menyebutkan sebagai destinasi wisata Desa Kalibukbuk harus memberikan kenyamanan dan keselamatan bagi para wisatawan yang ingin mengunjungi Desa Kalibukbuk.

Berdasarkan latar belakang di atas, maka rumusan masalah dalam penelitian ini adalah bagaimana peran dan orientasi Pemerintah Desa kalibukbuk dalam mengoptimalisasi pengelolaan pendapatan asli desa dan alokasi dana desa.

\section{Metode}

\section{Metode Analisis Data}

Metode penelitian adalah cara ilmiah yang dilakukan untuk mendapatkan data dengan tujuan tertentu (Lasa, 2009, 207). Kata ilmiah dalam Kamus Besar Bahasa Indonesia (KBBI) mempunyai makna bersifat keilmuan atau memenuhi syarat (kaidah) ilmu pengetahuan sehingga dapat dipertanggungjawabkan kebenarannya.

Metode analisis data yang digunakan dalam melakukan analisis keuangan dilakukan dengan menggunakan metode kualitatif. Menurut Sugiyono (2005) menyatakan bahwa metode kualitatif adalah suatu metode yang digunakan untuk menggambarkan atau menganalisis suatu hasil penelitian tetapi tidak digunakan untuk membat kesimpulan yang lebih luas. Menurut Whitney (1960), metode kualitatif adalah pencarian fakta dengan interprestasi yang tepat. Adapun masalah yang dapat diteliti dan diselidiki oleh penelitian kualitatif ini mengacu pada studi kuantitatif. Kegiatan penelitian ini meliputi pengumpulan data, analisi data, interprestasi data dan pada akhirnya dirumuskan suatu kesimpulan yang mengacu pada analisis tersebut.

\section{Lokasi Penelitian}

Lokasi dari penelitian ini adalah di Kantor Perbekel Desa Kalibukbuk, yang beralamat di Jalan Desa Kalibukbuk-Anturan, Anturan, Kecamatan Buleleng. 


\section{Subjek Penelitian}

Subjek penelitian ini adalah pihak-pihak yang terlibat dalam pemberian informasi terkait dengan penelitian yaitu Putu Lisa Swandewi sebagai Koordinator Keuangan di Kantor Perbekel Desa Kalibukbuk.

\section{Objek Penelitian}

Objek kajian penelitian ini adalah objek kajian yang menjadi titik berat perhatian suatu penelitian. Adapun objek kajian penelitian ini adalah peran dan orientasi Pemerintah Desa Kalibukbuk dalam mengoptimalisasikan pengelolaan pendapatan asli desa dan alokasi dana desa.

\section{Jenis dan Sumber Data}

Data merupakan sumber informasi yang didapatkan oleh penulis melalui penelitian yang dilakukan. Data yang diperoleh nantinya akan diolah sehingga menjadi informasi baru yang dapat dimanfaatkan oleh pembacanya.

Dalam penelitian ini, data diperoleh melalui Data Primer dan Data Sekunder. Data Primer adalah data yang diperoleh langsung dari subjek penelitian dengan menggunakan alat pengukuran atau alat pengambilan data secara langsung pada subjek sebagai sumber informasi untuk data yang dicari (Wiyono, 2011:131). Data Primer penelitian ini adalah data yang diperoleh langsung dari tanya jawab dengan Putu Lisa Swandewi sebagai Koordinator Keuangan di Kantor Perbekel Kalibukbuk.

Data Sekunder adalah jenis data yang diperoleh dan di gali melalui hasil pengolahan pihak kedua baik berupa data kualitatif maupun kuantitatif (Wiyono,2011:133). Data sekunder penelitian ini yaitu data yang diperoleh dari Laporan Rincian Struktur Perubahan Anggaran Pendapatan dan Belanja Desa Pemerintah Desa Kalibukbuk.

\section{Teknik Pengumpulan Data}

Dalam penelitian ini menggunakan 4 Teknik pengumpulan data, yakni Wawancara, Observasi, Studi Kepustakaan, dan studi Dokumentasi.

1. Metode Wawancara (Interview) yang digunakan dalam penelitian ini wawancara terstruktur, yang mana peneliti sudah mempersiapkan pertanyaan-pertanyaan secara terstruktur yang akan dijawab oleh informan atau partisipan. Dalam hal ini wawancara dilakukan oleh peneliti kepada Putu Lisa Swandewi sebagai Koordinator Keuangan di Kantor Perbekel Kalibukbuk, yang sudah disampaikan beberapa pertanyaan yang menunjang dari penelitian ini.

2. Observasi, merupakan salah satu teknik pengumpulan data yang tidak hanya mengukur sikap dari informasi (wawancara) namun juga dapat digunakan untuk merekam berbagai fenomena yang terjadi (situasi, kondisi).

3. Studi Pustaka, merupakan langkah awal dalam metode pengumpulan data. Studi pustaka merupakan metode pengumpulan data yang diarahkan kepada pencarian data dan informasi melalui dokumen-dokumen, baik dokumen tertulis, foto-foto, gambar, maupun dokumen elektronik yang dapat mendukung dalam proses penulisan.

4. Studi Dokumentasi, yang digunakan berupa literatur yang relevan sebagai pendukung penelitian ini yakni Laporan Rincian Struktur Perubahan Anggaran Pendapatan dan Belanja Desa Pemerintah Desa Kalibukbuk.

$\begin{array}{ll}\begin{array}{l}\text { 3. HasildanPembahasan } \\ \text { Profil Desa Kalibukbuk }\end{array} & \\ \text { Keterangan } & \text { Luas } \\ \text { Luas permukiman } & 65 \mathrm{Ha} \\ \text { Luas Persawahan } & 35 \mathrm{Ha} \\ \text { Luas Perkebunan } & 80 \mathrm{Ha} \\ \text { Luas Kuburan } & 1 \mathrm{Ha} \\ \text { Luas Taman } & 0,5 \mathrm{Ha} \\ \text { Luas Perkantoran } & 2 \mathrm{Ha}\end{array}$




\section{Luas Prasarana Lainnya $\quad 46.525 \mathrm{Ha}$ \\ Luas Total Wilayah Desa $295.025 \mathrm{Ha}$}

Letak dan Batas Wilayah Desa

Tabel 4.1 Wilayah Desa Kalibukbuk

$\begin{array}{ll}\text { Sebelah Utara } & \text { : Laut Jawa } \\ \text { Sebelah Selatan } & \text { : Desa Kayu Putih dan Desa Selat }\end{array}$

Sebelah Barat : Desa Kaliasam

Sebalah Timur: Desa Anturan

Desa Kalibukbuk terletak di pinggir pantai yang ombaknya tenang sepanjang tahun, kurang lebih $10 \mathrm{Km}$ di sebelah barat Kota Singaraja. Ada dua jalan yang bisa dilalui bila kita hendak mengunjungi Desa Kalibukbuk dari arah Kota Singaraja. Pertama, kita bisa memalui jalan baru (Marga Anyar) ke arah barat. Setalah menumpuh jarak kurang lebih $10 \mathrm{Km}$ yang pertama di jumpai adalah Desa Kalibukbuk itu. Jalan ini dibuat dengan cara terencana pada zaman Belanda. Kedua, untuk sampai di Desa Kalibukbuk bisa juga melalui jalan pedesaan melalui Desa Baktiseraga, Desa Pemaron, Desa Tukad Mungga, Desa Anturan dan sampailah di Desa Kalibukbuk. Jalan ini sudah ada sejak zaman dahulu.

Pusat Desa Kalibukbuk ditandai dengan persimpangan jalan 5 (lima) arah atau simpang lima. Desa Kalibukbuk yang kita lihat sekarang ini sudah berbeda dengan keadaan pada masa lampau, katakanlah 20 tahun yang lalu. Waktu itu penduduknya hidup secara tradisional dari pertanian seperti kelapa dan perternakan seperti berternak sapi, bebek, ayam dan kerbau. Disamping itu mereka juga ada berkerja sebagai nelayan, buruh atau tukang bangunan. Namun itu dahulu, Desa kalibukbuk adalah desa yang sudah menjadi tempat tujuan wisata yang cukup terkenal di manca negara. Hal ini dapat kita lihat dengan telah tercantumnya Desa Kalibukbuk di buku panduan wisata (Guide Book) di dalam dan di luar negeri. Bahkan di internet sudah banyak disebutkan Desa Kalibukbuk ini. Mungkin masih ada di antara kita yang belum mengetahui bagaiman proses transformasi ini berlangsung dan keterlibatan masyarakatnya, dari masyarakat tani ke arah pariwisata.

Dimulainya dengan suatu rintisan atau trobosan yang dilakukan oleh warga desa, maka kepariwisataan berkembang bersama-sama dengan lima desa tetangganya membentuk satu kawasan wisata. Orang-orang tua dahulu meyebut desa ini dengan nama "Tanah Gesar". Tetapi sekarang nama tanah gesar jarang terdengar kecuali kalau disebut oleh kalangan orang-orang tua. Yang lebih sering dipakai Kalibukbuk. Ada beberapa orang yang mengkaitkan nama Kalibukbuk dengan kalingga, sebuah nama kota di India. Namun perlu disebutkan juga disini adanya cerita rakyat atau legenda yang menceritakan bahwa zaman dahulu Kerajaan Tanah Gesar (Kalibukbuk) dikalahkan oleh sejenis ikan laut yang disebut ikan bano yang berparuh lancip seperti anak panah. Banyak anggota masyarakat yang terbunuh di pantai yang membuat rakyat resah dan menjauhi pesisir pantai. Lalu Raja waktu itu berupaya menolong rakyatnya dengan mengadakan sayembara. Datanglah seorang pemuda yang menyatakan kesanggupannya mengalahkan ikan bano tersebut dengan imbalan meminta sebagian wilayah Tanah Gesar, dan Raja pun setuju. Memang benar pemuda tersebut bisa mengalahkan ikan bano tersebut. Tetapi Raja malah berbalik pikiran, dan pemuda itu dibunuh. Dari arah selatan datanglah banjir bandang pada waktu itu (Waktu = kala/kali) sang raja bingung atau panik (lbuk) maka sejak saat iitulah desatersebut di beri nama Desa Kaliibuk/Kalibukbuk sampai sekarang dengan adanya bukti peninggalan yaitu pura dalem panji dan situs budha.

\section{Visi dan Misi Pemerintah Desa Kalibukbuk 2014-2020}

Visi pemerintah Desa Kalibukbuk 2014-2020 yaitu terwujudnya Desa Kalibukbuk yang aman, tentram dan sejahtera berdasarkan Tri Hita Karana. Sedangkan Misi Desa Kalibukbuk adalah sebagai berikut :

a. Mewujukan kondisi Desa Kalibukbuk yang BALI (Bersih, Aman, Lestari dan Indah) terbangunnya hubungan harmonis dikalangan masyarakat sesuai dengan konsep Tri Hita Karana. 
b. Mewujudkan masyarakat yang adil dan makmur berlandaskan pancasila

c. Mewujudkan Desa Kalibukbuk sebagai desa yang aman damai dan sejahtera

\section{Sumber Dana Pemerintah Desa Kalibukbuk}

Desa Kalibukbuk dalam menjalankan program pembangunan dan program kepemerintahan mempunyai tujuh sumber pendapatan, yang mana berasal dari Pendapatan Asli Desa (PAD), Dana Desa (Dari APBN), Alokasi Dana Desa (ADD), Bagi Hasil Pajak Daerah (BHP), Bagi Hasil Restribusi Daerah (BHR), Bantuan Keuangan Provinsi (BKP), Pendapatan Lain-lain (PLL). Pada tahun 2018, pendapatan yang diterima oleh Kantor Desa Kalibukbuk dilihat dari Laporan Berikut Rincian Struktur Perubahan Anggaran Pendapatan dan Belanja Desa Pemerintah Desa Kalibukbuk pada Tahun 2018.

\section{RINCIAN STRUKTUR}

\section{ANGGARAN PENDAPATAN DAN BELANJA DESA \\ PEMERINTAH DESA KALIBUKBUK}

TAHUN ANGGARAN KALIBUKBUK 2018

\begin{tabular}{|c|c|c|c|c|c|c|}
\hline \multicolumn{4}{|c|}{ Kode Rekenin } & Uraian & $\underset{R p)}{\text { Anggaran }}$ & Ket \\
\hline \multicolumn{4}{|c|}{1} & 2 & 3 & 4 \\
\hline 1 & & & & PENDAPATAN & $2.194 .446 .138,59$ & \\
\hline 1 & 1 & & & Pendapatan Asli Desa & $2.263 .423,00$ & \\
\hline 1 & 1 & 1 & & Hasil Usaha & $2.263 .423,00$ & \\
\hline 1 & 1 & 2 & & Hasil Aset & & \\
\hline 1 & 1 & 3 & & $\begin{array}{l}\text { Swadaya, Partisipasi dan Gotong } \\
\text { Royong }\end{array}$ & & \\
\hline 1 & 1 & 4 & & $\begin{array}{l}\text { Lain-lain Pendapatan Asli Desa } \\
\text { yang Sah }\end{array}$ & & \\
\hline 1 & 2 & & & Pendapatan Transfer & 1.532.082.715,59 & \\
\hline 1 & 2 & 1 & & Dana Desa & $789.725 .639,38$ & \\
\hline 1 & 2 & 1 & 1 & Dana Desa & $789.725 .639,38$ & \\
\hline 1 & 2 & 2 & & $\begin{array}{l}\text { Bagian dari hasil Pajak dan } \\
\text { Retribusi daerah kabupaten/kota }\end{array}$ & $118.286 .678,06$ & \\
\hline 1 & 2 & 2 & 1 & Bagi hasil Pajak daerah & $103.576 .498,76$ & \\
\hline 1 & 2 & 2 & 2 & Bagi hasil Retribusi daerah & $14.710 .179,30$ & \\
\hline 1 & 2 & 3 & & Alokasi Dana Desa & $624.070 .398,15$ & \\
\hline 1 & 2 & 3 & & Alokasi Dana Desa & $624.070 .398,15$ & \\
\hline
\end{tabular}




\begin{tabular}{|l|l|l|l|l|l|l|l|} 
& & & & & & \\
\hline $\mathbf{1}$ & $\mathbf{2}$ & $\mathbf{4}$ & & & Bantuan Keuangan & $600.000 .000,00$ & \\
\hline 1 & 2 & 4 & 1 & & Bantuan Provinsi & $600.000 .000,00$ & \\
\hline 1 & 2 & 4 & 2 & & Bantuan Kabupaten/ Kota & $60.100 .000,00$ & \\
\hline & & & & & & $60.100 .000,00$ & \\
\hline $\mathbf{1}$ & $\mathbf{3}$ & & & & Pendapatan Lain-lain & & \\
\hline 1 & 3 & 1 & 1 & $\begin{array}{l}\text { Hibah dan Sumbangan dari Pihak } \\
\text { ke-3 yang tidak mengikat }\end{array}$ & $\begin{array}{l}\text { Lain-lain Pendapatan Desa Yang } \\
\text { Sah }\end{array}$ & $2.194 .446 .138,59$ & \\
\hline 1 & 3 & 2 & 2 & & & \\
\hline & & & & & JUMLAH PENDAPATAN & & \\
\hline
\end{tabular}

Tabel 4.2 Laporan Rincian Struktur Perubahan Anggaran Pendapatan dan Belanja Desa Pemerintah Desa Kalibukbuk

Dari Laporan Rincian Pendapatan Desa Kalibukbuk dapat diketahui bahwa pendapatan yang dimiliki Desa kalibukbuk pada tahun 2018 adalah Pendapatan Asli Desa (PAD) sebesar Rp 2.263.423,00 Dana Desa (Dari APBN) sebesar Rp 789.725.639,38, Alokasi Dana Desa (ADD)sebesar Rp 624.070.398,15, Bagi Hasil Pajak Daerah (BHP) sebesar Rp 103.576.498,76, Bagi Hasil Restribusi Daerah (BHR) sebesar Rp 14.710.179,30, Bantuan Keuangan Provinsi (BKP) sebesar Rp 600.000.000,00, Pendapatan Lain-lain (PLL) sebesar Rp 60.100.000,00. Total pendapatan Desa Kalibukbuk pada tahun 2018 adalah sebesar Rp2.194.446.138,59 masuk ke dalam rekening desa. PAD, BKP, Dana Desa dan PLL digunakan untuk kegiatan pembangunan desa, pemberdayaan posyandu dan pemberdayaan desa lainya. ADD, BHP dan BHR digunakan untuk kegiatan penyelenggaraan pemerintahan seperti pembayaran gaji karyawan dan pembiayaan kantor.

\section{PENDAPATAN DESA KALIBUKBUK Tahun 2018}

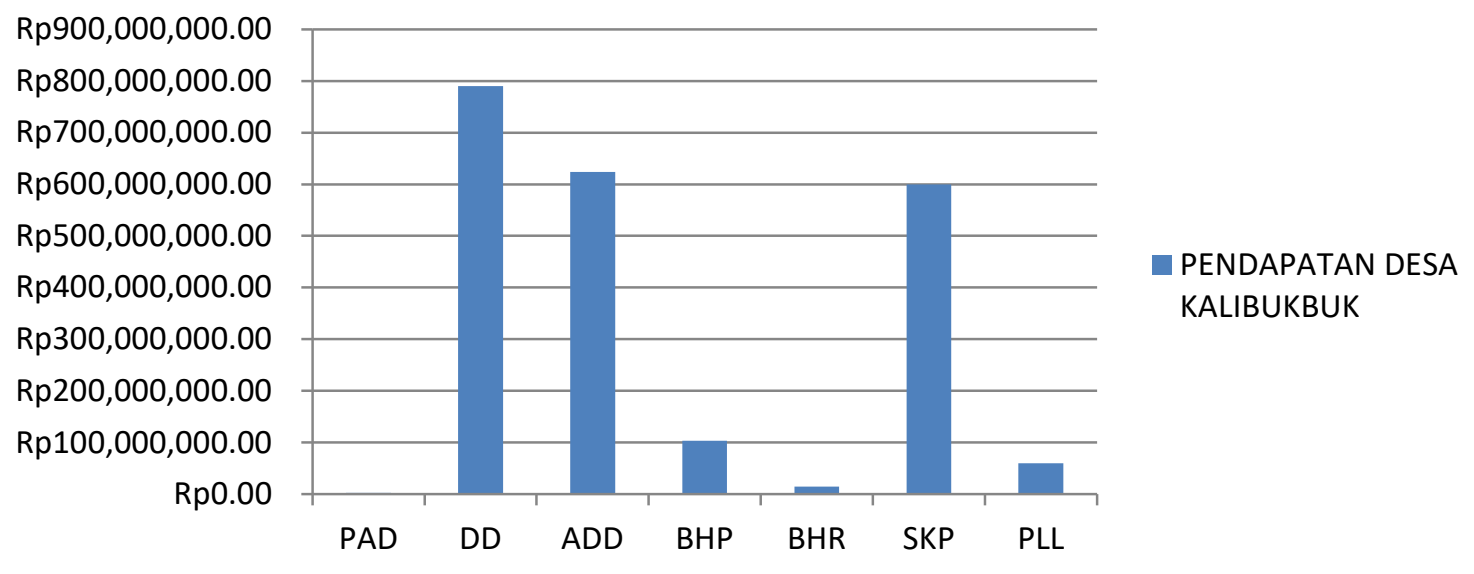

Gambar 4.1 Pendapatan Desa Kalibukbuk Tahun 2018

\section{Perencanaan dan Pengelolaan Pemerintah Desa Kalibukbuk}

Pelaksanaan pengelolaan APBDesa yang terdapat di Desa Kalibukbuk ditinjau dari mekanisme penyaluran dana sesuai petunjuk pelaksanaan yang ada. Sehingga dapat dikatakan bahwa proses pelaksanaan APBDesa mengacu pada realisasi pembangunan fisik 
yang telah direncanakan sebelumnya. Perencanaan Desa Kalibukbuk dilakukan dengan musyawarah desa. Pernyataan ini didukung oleh pernyataan informan yaitu Putu Lisa Swandewi yang menyatakan bahwa :"Perencanaan-perencanaan dibuat di Desa Kalibukbuk yaitu melalui musyawarah desa, di mana kita mengumpulkan aspirasi-aspirasi masyarakat, Oleh tim verifikasi perencanaan dikumpulkan dan dipilih perencanaan mana yang akan diajukan kepada Sekertaris Desa. Kepala Desa akan memilih perencanaan mana yang dapat dilakukan. Perencanan yang disetujui lalu akan dibuatkan RAB Desa dan jika tidak ada masalah maka dibuatkanlah APBDesa, lalu diserahkan ke Kantor Camat dan PMD Kabupaten, apakah perencanaan yang diajukan dapat direalisasikan atau tidak."

Rencana untuk mengoptimalkan pendapatan asli desa dan alokasi dana umum didanai dari rekening desa, yang telah terealisasikan untuk Desa Kalibukbuk pada tahun 2018 adalah sebagai berikut :

a. Bidang Pembangunan Desa

1. Kegiatan fasilitasi, pembangunan, pembinaan dan pengelolaan pendidikan anak usia dini (paud)

2. Kegiatan fasilitasi dan pemeberian bantuan RTS, lansia, dan penyandang cacat (difabel)

3. Kegiatan pembangunan dan pemeliharaaan jalan lingkungan

4. Kegiatan pembangunan, penataan dan pemeliharaan pahrayangan desa

5. Kegiatan fasilitasi pembangunan, pemeliharaan dan penataan setra desa

6. Kegiatan fasilitasi pembangunan, pemeliharaan dan penataan subak

7. Kegiatan fasilitasi, pengembangan dan pengadaan upacara keagamaan

b. Bidang Pembinaan Kemasyarakatan

1. Kegiatan pembinaan dan peningkatan kapasitas linmas

2. Kegiatan pelaksanaan peringatan hari-hari besar agama

3. Kegiataan fasilitas dan pembinaan sekeha teruna teruni

4. Kegiatan pembinaan lembaga adat

5. Kegiatan pembinaan prestasi bidang olah raga masyarakat desa

6. Kegiatan penyelengaraan porseni tingkat desa

c. Bidang Pemberdayaan Masyarakat

1. Kegiatan penyusunan KKP desa

2. Kegiatan fasilitas dan penyelenggaraan festival wisata desa

3. Kegiatan pelatihan srathi banten

4. Kegiatan penguatan kapasitas kader posyandu

5. Kegiatan peningkatan minat bacamasyarakat desa

6. Kegiatan pengelolaan pos kesehatan masyarakat (Poskedes, Polides, Posbindu, dan Posyandu)

\section{PENGELOLAAN PENDAPATAN DESA KALIBUKBUK YANG TELAH TEREALISASI}

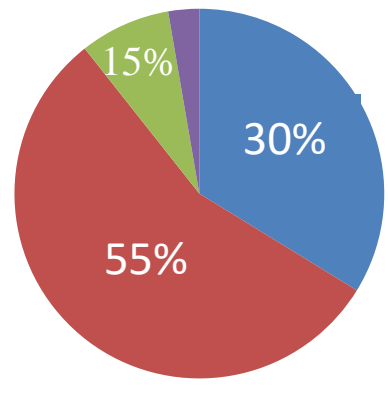

PENYELENGGARAAN

BIDANG PEMBANGUNAN

PEMBINAAN

MASYARAKAT 


\section{Gambar 4.2 Pengelolaan Pendapatan Desa Kalibukbuk Yang Telah Terealisasi}

Bukti fisik yang peneliti dapat amati langsung saat melakukan observasi pada Desa Kalibukbuk adalah sudah ada 25 gang yang telah diperbaiki atau telah dibetonisasi, namun masih ada beberapa gang yang masih berupa tanah. Maka dari itu perencanaan kegiatan pembangunan dan pemeliharaan jalan lingkungan dapat dikatan sudah terealisasi pada tahun 2018. Pernyataan ini didukung dengan Rincian Belanja Desa Kalibukbuk pada lampiran 1.

\section{Faktor Pendukung Dalam Mengoptimalkan Pedapatan Asli Desa dan Alokasi Dana Desa. \\ Di Desa Kalibukbuk, faktor pendukung dari pelaksanaan program Pendapatan Asli} Desa dan Alokasi Dana Desa dapat diketahui dari kutipan wawancara dengan Koordinator Keuangan sebagaimana berikut. "salah satu faktor pendukungnya adalah tingginya sumber daya masyarakat dan partisipasi masyarakat yakni dalam Musyawarah Desa."(Putu Lisa Swandewi, 2018)

Berdasarkan kutipan diatas dapat diketahui bahwa koordinator keuangan Desa Kalibukbuk menyatakan faktor pendukung dari pelaksanaan program Pendapatan Asli Desa dan Alokasi Dana Desa adalah tingginya partisipasi dan sumber daya masyarakat. Tingginya tingkat partisipasi masyarakat dalam pelaksanaan program Pendapatan Asli Desa dan Alokasi Dana Desa yakni dalam Musyawarah Desa dapat dilihat dari tingkat kehadiran dan jumlah usulan masyarakat cukup banyak. Masyarakat Desa Kalibukbuk masih melestarikan budaya gotong royong dalam mendukung pengelolaan Pendapatan Asli Desa dan Alokasi Dana Desa khususnya pada tahap pelaksanaan kegiatan. Selain partisipasi masyarakat keberhasilan program ini tidak dapat dipisahkan dari unsur sumber daya manusia.

Sumber daya manusia merupakan pelaksana yang sangat menentukan keberhasilan dari implementasi suatu kebijakan, termasuk program Pendapatan Asli Desa dan Alokasi Dana Desa. Selain adanya faktor pendukung mengenai Pendapatan Asli Desa dan Alokasi Dana Desa, tentu saja terdapat faktor penghambat di dalamnya. Terdapat beberapa perencanaan Pemerintah Desa Kalibukbuk yang tidak dapat terealisasikan karena ada dana yang macet dan tidak adanya peraturan yang mendukung. Hal ini didukung dengan penyataan Putu Lisa Swandewi selaku Koordinator Keuangan Desa Kalibukbuk yang menyatakan bahwa : "Kendala yang pernah dialami dalam mengoptimalkan pengelolaan pendapatan desa, yaitu saat pembuatan struktur organisasi dana yang diperlukan belum sampai ke rekening desa dan jika dana yang ada dicairkan, perencanaan tersebut juga tidak dapat diselesaikan dalam satu periode maka dari itu, dana tersebut disisihkan dan perencanaan ditunda. Kendala lainya, pihak Pemerintah Desa Kalibukbuk menganggarakan honor TK. Ternyata dari peraturan tidak diperbolehkan, karena belum ada peraturan yang dapat menguatkan perencanaan tersebut. Jadi perencanaan tersebut tidak dapat direalisasikan."

\section{Simpulandan Saran Simpulan}

Berdasarkan hasil penelitian di atas dapat disimpulkan bahwa proses pelaksanaan APBDesa mengacu pada realisasi pembangunan fisik dan non fisik yang telah direncanakan sebelumnya. Bukti fisik yang peneliti dapat amati langsung saat malakukan observasi pada Desa Kalibukbuk adalah sudah ada 25 gang yang telah diperbaiki atau telah dibetonisasi namun masih ada beberapa gang yang masih berupa tanah. Maka dari itu perencanaan kegiatan pembangunan dan pemeliharaan jalan lingkungan sudah terealisasi pada tahun 2018. Faktor pendukung dari pelaksanaan program Pendapatan Asli Desa dan Alokasi Dana Desa adalah tingginya sumber daya masyarakat dan partisipasi masyarakat yakni dalam Musyawarah Desa. Namun dalam mengoptimalkan perencanaan pendapatan asli desa dan alokasi dana umum terdapat faktor penghambat di dalamnya. Beberapa perencanaan yang dilakukan Pemerintah Desa Kalibukbuk tidak dapat terealisasi karena adanya dana yang macet dan tidak adanya peraturan yang mendukung. 


\section{Saran}

Berdasarkan kesimpulan di atas maka penulis mengajukan beberapa saran atau rekomendasi:

1. Bagi Pemerintah

Sebaiknya pemerintah Desa Kalibukbuk merumuskan strategi dalam mengoptimalkan program yang telah direncanakan supaya dapat terealisasi pada periode yang bersangkutan.

2. Bagi Peneliti Selanjutnya

Sebaiknya peneliti mencari informasi dari kalangan masyarakat agar penelitian tidak hanya melihat dari persepsi pemerintah desa tersebut.

\section{DAFTAR PUSTAKA}

Indra, Krisna. 2016. Pengertian PAD (Pendapatan Asli Daerah). Diunduh tanggal 27 Desember 2018. https://materipengetahuanumum.blogspot.com/2016/10/pengertianpendapatan-asli-daerah.html.

Khaitari, Aga. 2008. Peran dan Orientasi Pemda Dalam Optimalisasi Pendapatan Asli Daerah dan Dana Alokasi Umum (Studi Kasus Pada Pemerintahan Daerah Kabupaten Sleman). Diunduh tanggal 28 Desember 2018. https://webcache.googleusercontent.com/search?q=cache:nKT9n-

88j|4J:https://anzdoc.com/download/peran-dan-orientasi-pemda-dalam-optimalisasipendapatan-asli.html+\&cd=1\&hl=id\&ct=clnk\&gl=id.

Pasaribu, Mangihot. 2016. Pengertian Orientasi. Diunduh tanggal 28 Desember 2018. http://mangihot.blogspot.com/2016/11/pengertian-orientasi.html.

Puspawardani, Wida. 2017. Pengelolaan Anggaran Pendapatan Dan Belanja Desa Pemerintah Desa Di Desa Parakanmangu Kecamatan Parigi Kabupaten Pangandaran. Diunduh tanggal 27 Desember 2018. https://webcache.googleusercontent.com/search?q=cache:DaEOBkX7oqUJ:https://jur nal.unigal.ac.id/index.php/dinamika/article/download/379/381+\&cd=2\&hl=id\&ct=clnk\& gl=id.

Rudisastrawan. 2015. Sejarah Desa Kalibukbuk. Diunduh tanggal 27 Desember 2018. https://rudisastrawanwira.wordpress.com/2015/05/12/sejarah-desa-kalibukbuk/.

Wikipedia. 2018. Dana Alokasi Umum. Diunduh tanggal 28 Desember 2018. https://id.wikipedia.org/wiki/Dana Alokasi Umum. 